\title{
SURGICAL CORRECTION OF ENDOVASCULAR ANEURYSMS: REPAIR COMPLICATIONS
}

\author{
Petr Utikal ${ }^{\mathrm{a}}$, Martin Koecher ${ }^{\mathrm{b}}$, Jirina Koutna ${ }^{\mathrm{c}}$, Petr Bachleda ${ }^{\mathrm{a}}$, Petr Drac ${ }^{\mathrm{a}}$, Marie Cerna ${ }^{\mathrm{b}}$, \\ Herman J. ${ }^{\mathrm{a}}$ \\ a $2^{\text {nd }}$ Clinic of Surgery, University Hospital Olomouc, Czech Republic \\ ${ }^{b}$ Clinic of Radiology, University Hospital Olomouc \\ c Clinic of Anaesthesiology, University Hospital Olomouc \\ e-mail:petr.utikal@fnol.cz
}

Received: April 12, 2006; Accepted: June 5, 2006

Key words: Aorta/Aneurysms/Repair/Endovascular/Complications/Corrections/Additional procedures/Adjuvant procedures/Open surgery

The authors describe their experience with the use of 21 open surgical corrections after endovascular abdominal aneurysm repair, reporting the frequency, type and outcome of these procedures in their group of 165 patients treated during a 10-year period.

\section{INTRODUCTION}

Based on a lower operating risk, endovascular aneurysm repair (EVAR) is generally an accepted alternative to abdominal aortic aneurysms (AAA) treatment despite its tendency to technical failure with a high re-intervention rate ${ }^{1-5}$.

Fortunately, most EVAR specific complications related to the aneurysm and the stentgraft (such as endoleaks, stentgraft migration, kinking, stenosis or occlusion) are usually successfully solved to facilitate or preserve the stentgraft function or passage and to achieve acceptable primary technical and longterm clinical success. This complications solution involving endovascular or surgical procedures, such as corrections and conversions, is reported in $10-34 \%$ of cases ${ }^{1,6-12}$. Well accepted by patients and technically mostly successful endovascular procedures are the methods of choice for most solutions to EVAR complications ${ }^{13-15}$. Surgical procedures are indicated in cases when endovascular repair is impossible, if it has failed or its success probability is low ${ }^{16}$.

\section{METHODS}

\section{Surgical correction classification}

Sugical corrections (SC) are defined as any primary or secondary additional procedures performed to facilitate, augment or preserve the effect of the principle EVAR procedure using the methods of classical vascular surgery. Primary procedures are performed at the time of the initial EVAR procedure and they are classified as planned or unplanned. The planned procedures are part of a preformulated operative strategy and are taken into account in the planning and indication of AAA for EVAR. The unplanned procedures are those, which deal with im- mediate EVAR complications. Secondary procedures are performed to solve complications during the subsequent operation as early (within the first 30 days from EVAR) or late (after 30 days) and the indication can be acute or elective ${ }^{9,11,17}$.

\section{Surgical correction procedures \\ Ligature}

Ligature is a surgical (extravascular) method of vessel occlusion. It can be used in cases of type II endoleaks from AAA sac branches retrograde flow. The artery is ligated by suture ligature (clip ligation can be also used) at one place or at two places and the artery is divided between them to stop the blood flow. Ligation mostly involves minilaparotomic approach (Fig. 1) (ref. $\left.{ }^{18}\right)$.

\section{Banding}

Banding refers to an external ligation around the artery with an implanted stentgraft. This solves the problematic stentgraft fixation connected with type Ia,b endoleak in the anchor zone of the stented aneurysmal or iliac neck (proximal or distal) anastomoses. It is inserted with a dacron strip (on aorta) or two silon ligatures (on iliac arteries) around the artery with an endovascularly implanted inflated balloon catheter, by retroperitoneal approach (to iliac arteries) or from minilaparotomy (to aorta) (Fig. 2, 3) (ref. ${ }^{18-22}$ ).

\section{Thrombectomy}

Surgical indirect thrombectomy is performed using a balloon catheter (Fogarty) through common femoral artery (CFA) access in case of the stentgraft occlusion.

Thrombectomy has to be followed by solving the cause of thrombosis (stentgraft or iliac artery stenosis), if found. Additional radiological endovascular procedures are used: balloon dilatation and wall stent insertion. 

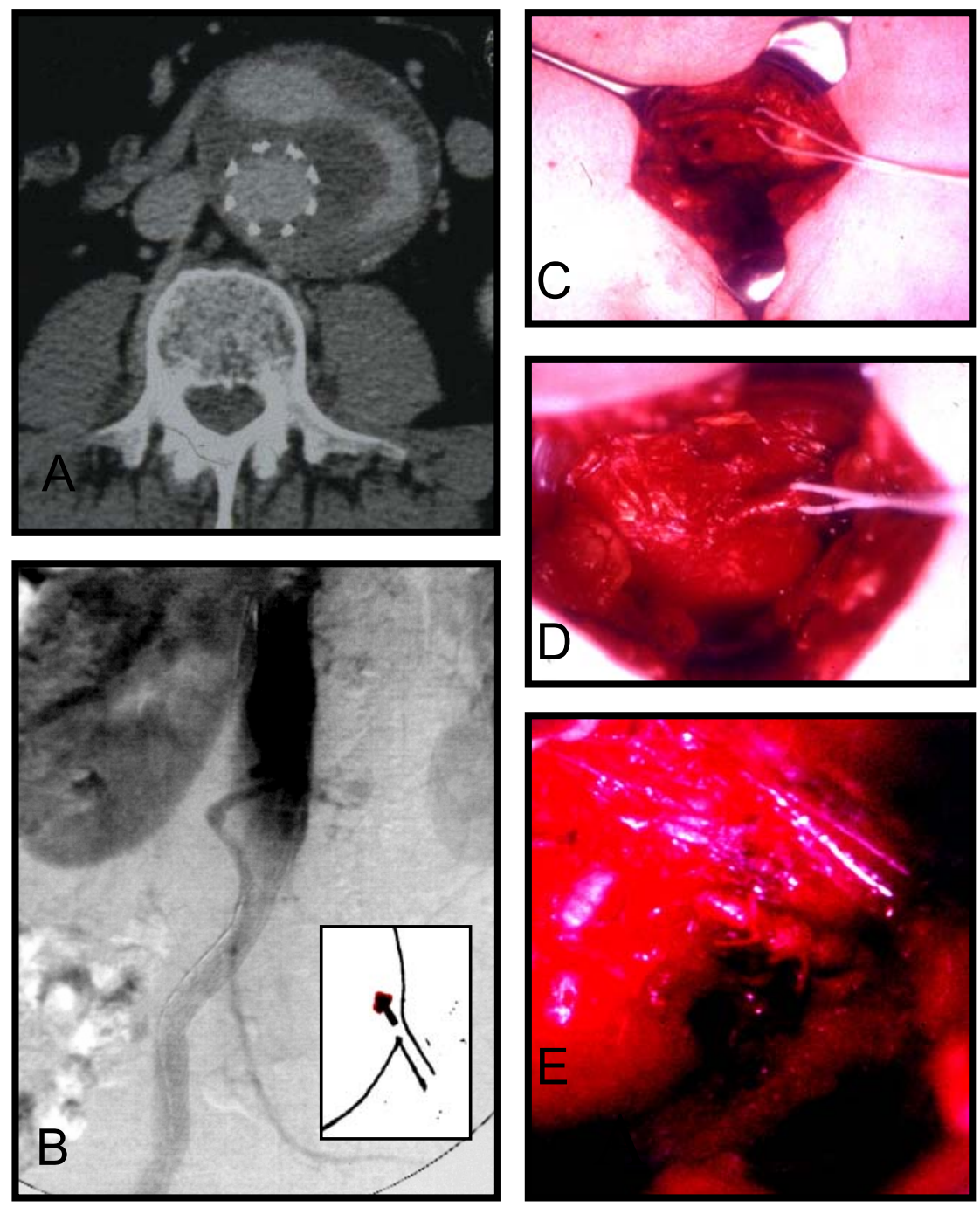

Fig. 1. 55-year-old male with EVAR by aortouniiliac stentgraft.

Type IIa endoleak attributed to retrograde flow in IMA, successfully treated by ligature 20 months after primary procedure.

A: CTA transverse section of aneurysmal sac with stentgraft and endoleak.

B: Selective DSA of superior mesenteric artery shows retrograde IMA filling as the cause of endoleak

C, D, E: AAA sac with IMA approached by minilaparotomy. The artery is divided between two ligatures.

\section{Endarterectomy, patch plastic}

Where stentgraft thrombosis is caused by severe CFA atherosclerotic changes (AS), direct surgical endarterectomy with ePTFE patch plastic is indicated.

\section{Femoral-femoral crossover bypass}

Femoral-femoral crossover bypass is performed for extraanatomical limb revascularisation in case of iliac occlusion on one side. Dacron prosthesis (diameter 7 or 8 ) is anastomosed by prosthesis end to the side of common femoral artery (CFA) on both sides and using a tunneller it is subcutaneously placed in the suprapubic region (Fig. 4).

In this paper we describe our experience in primary unplanned or secondary surgical corrections of EVAR complications performed to prevent sac rupture or to solve limb ischaemia. Surgical corrections connected with EVAR access site were not incorporated into this study.

\section{PATIENTS, RESULTS}

Between 1996 and 2005, we treated endovascularly 165 patients with asymptomatic AAA. One type of stentgraft system: Ella (ELLA CS, Hradec Králové, Czech Republic) was used for AAA exclusion in all patients. Stentgraft configuration included 3 aortic tubes, 136 bifurcated grafts, and 26 aortouniiliac grafts. In 7 (4.2\%) patients immediate, early or late conversion to open surgery was necessary. On the other hand, in 38 (23\%) patients, a total of 51 immediate, early and late endovascular cor- 

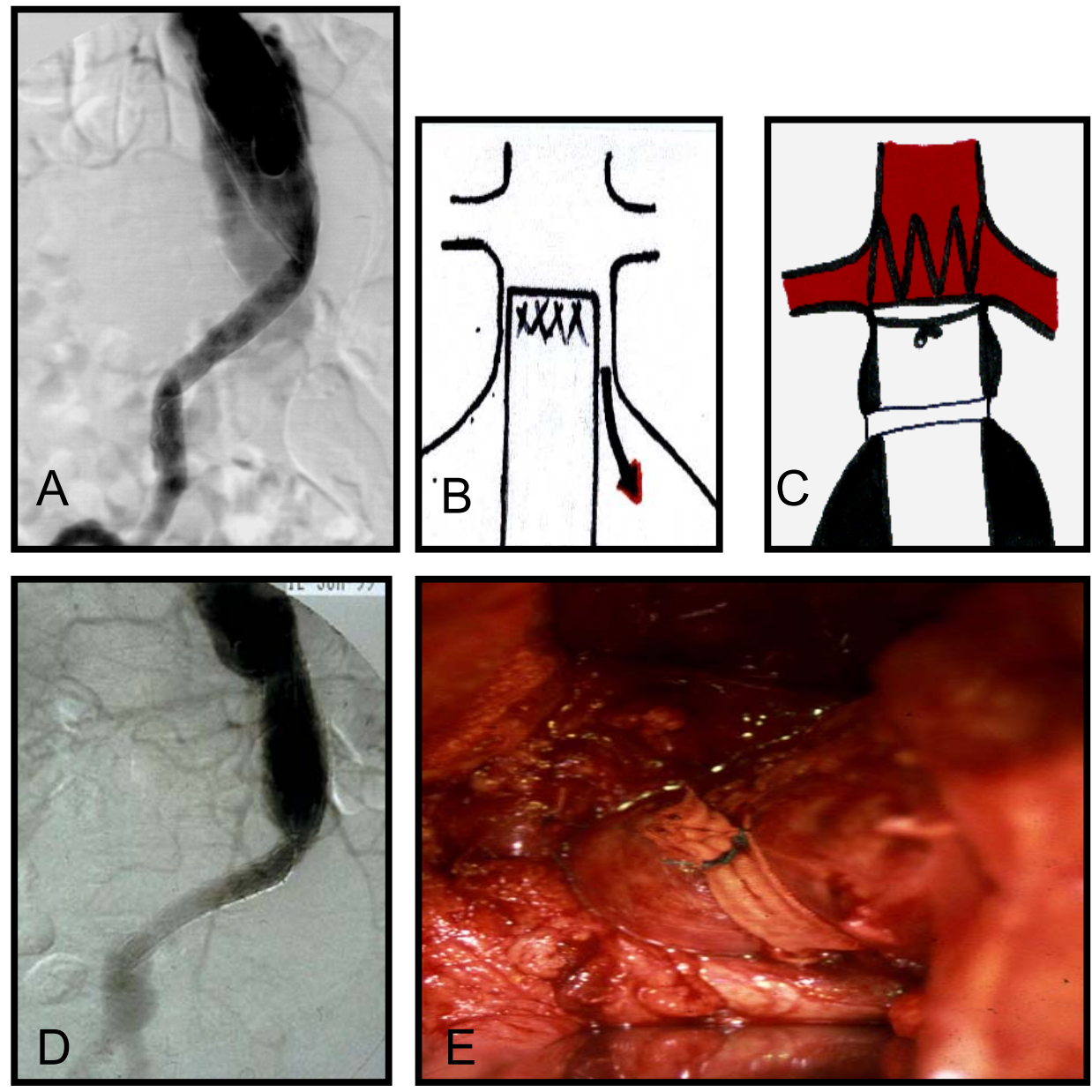

Fig. 2. 65-year-old male with EVAR by aortouniiliac stentgraft.

Type Ia endoleak attributed to failed stentgraft sealing in proximal aortic neck, successfully treated by banding.

A: Post primary procedure DSA shows type Ia aortic endoleak

B, C: Drawing of type Ia endoleak and its correction by proximal neck banding

D: DSA after successful correction without signs of type Ia endoleak

E: Peroperative view of proximal aortic neck banding approached by minilaparotomy

rections $(n=15)$, endovascular conversions $(n=2)$ and surgical corrections $(n=34)$ were successfully used, and the primary technical success of $93.9 \%$, primary assisted technical success of $98.8 \%$ and secondary clinical success of $95.7 \%$. were achieved ${ }^{23-26}$. The 34 surgical corrections representing $67 \%$ of the total corrections were performed immediately $(n=4)$, during the first next 30 days $(n=10)$, and during the follow up period (min 1 month, max 120 months $)(n=20)$ in 21 patients. The endoleak corrections $(n=721 \%)$ were performed immediately $(n=2)$ and electively $(n=5)$ in 7 patients. Ligature of inferior mesenteric artery (IMA) $(n=2)$ was electively in hemodynamically significant type II endoleak used (Fig. 1). Proximal aortic banding $(n=4)$ was performed immediately in primary type Ia endoleak $(n=2)$ and electively in the secondary one $(n=2)$ (Fig. 2). Distal iliac banding $(n=1)$ was performed electively in persistent distal iliac type Ib endoleak (Fig. 3). All the surgical corrections due to stentgraft thrombosis $(n=2779 \%)$ in 14 patients were performed acutely. We performed surgical thrombectomy $(n=18)$ (one or two times repeated in 4 patients) followed by common femoral endarterectomy with patch plastic $(n=5)$ and external iliac artery straightening $(n=1)$ and femoral-femoral cross over bypass $(n=3)$ to solve the cause of thrombosis (Fig. 4). The procedures were performed under regional (spinal or epidural) $(n=27)$ or general $(n=7)$ anesthesia. All the surgical corrections were fully technically and clinically successful and all of the femoral-femoral crossover bypasses remain primarily patent. There was no death and no severe morbidity (cardiac or pulmonary) following surgical corrections.

\section{DISCUSSION}

Endovascular correction or conversion is determined to be the method of choice for most EVAR complications repair ${ }^{7,9,11-15}$. The concept of having a „tool-box“ con- 

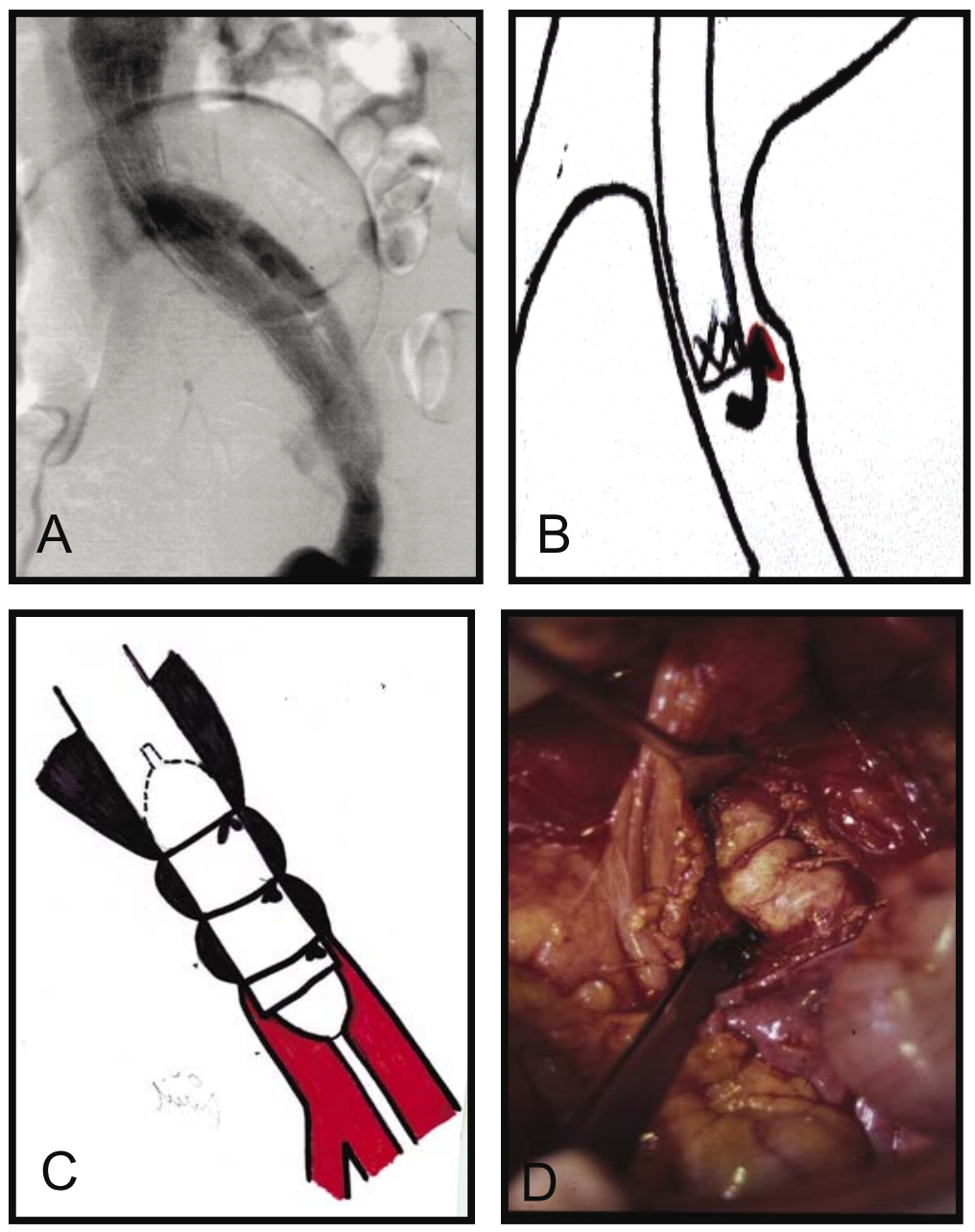

Fig. 3. 75-year-old male with EVAR by aortouniiliac stentgraft.

Type Ib endoleak attributed to failed stentgraft sealing in the distal iliac neck, successfully treated by banding.

A: Post primary procedure DSA shows type Ib iliac endoleak

B: Drawing of the type Ib iliac endoleak

C: Drawing of distal iliac banding

D: Peroperative view of retroperitoneally approached distal iliac banding

taining a variety of devices for endovascular corrections makes this method even more attractive ${ }^{27}$. Surgical repair is thus indicated where endovascular repair is impossible or where it has faile ${ }^{16}$. Some reports present more frequently surgical procedures (as the technically easier option) used for complications solution early in their EVAR experience in contrast to later periods 9 . We preferred endovascular correction or conversion procedures, which, when indicated were mostly successful ${ }^{23-26}$. Nevertheless, we do not hesitate to apply surgical correction where it is deemed useful ${ }^{18,21}$. Most elective re-interventions are due to endoleak. The majority of acute re-interventions are required due to stentgraft thrombosis with acute limb ischaemia ${ }^{7,9,11,14-15}$.

Our experience with EVAR complications requiring intervention is comparable with other presented reports. Type I endoleaks, especially the late proximal ones, are absolutely indicated for repair, and this was also the case in our patients ${ }^{27-28}$. In our early experience, immediate type Ia endoleaks in our patients were caused by failed stentgraft placement in the short conical neck. Secondary type Ia endoleaks developed 6 and 8 months after EVAR caused by failed stentgraft sealing in the short conical proximal neck of large diameter $(30 \mathrm{~mm})$ as a late result of primary morphological indication mistake (Fig. 2). Iliac distal endoleak that occurred 6 months after EVAR was caused by non-matching stentgraft and common iliac artery diameters resulting from incorrect measurement again (Fig. 3).

In agreement with other authors, our management strategy for type II endoleak is conservative, and repair is indicated in case of hemodynamic importance with high flow and an increase in aneurysm size ${ }^{27-28}$. There were $14(8.8 \%)$ secondary type II endoleaks observed in our 

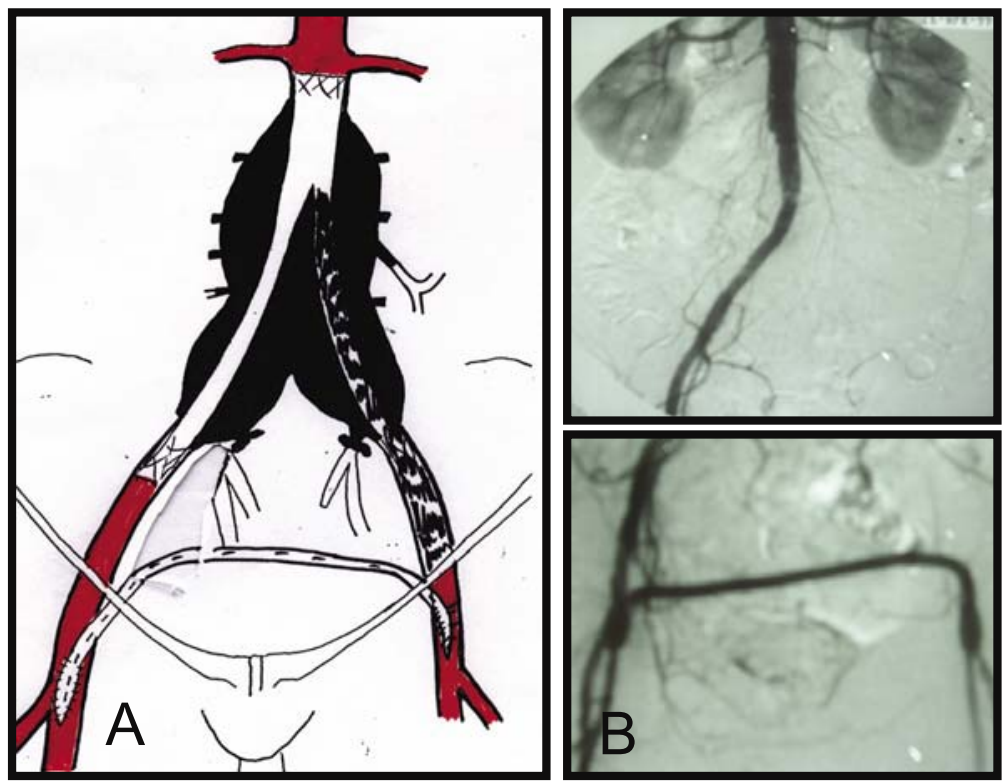

Fig. 4. 65-year-old female with EVAR by bifurcated stentgraft The lower extremity revascularisation using femoral-femoral cross over bypass in case of bifurcated stentgraft one limb irreparable thrombosis

A: Drawing of extraanatomical revascularisation by femoralfemoral bypass

B: DSA of femoral- femoral bypass

patients but only 2 ( $1.3 \%$ ) of hemodynamic significance (both attributed to retrograde flow in IMA) were repaired $11(n=1)$ and $20(n=1)$ months after the EVAR (Fig. 1). The incidence of stentgraft thrombosis varies about $2 \%$ and occurred almost exclusively in only one limb of bifurcated grafts. Stentgraft or iliac-femoral artery region stenoses are frequent causes. Stentgraft stenosis is mostly caused by stentgraft kinking or twisting in an angulated aneurysmal sac and in the iliac artery or by its compression in a narrow distal aneurysmal sac when a bifurcated graft is used. They all result from a primary less suitable aneurysmal morphology or its secondary changes over the time. Paradoxically, reduction in aneurysmal sac size after successful EVAR may lead to kinking, with progression to thrombosis ${ }^{27,29}$. Iliac-femoral artery stenosis is mostly caused by progression of AS changes in this location. There was critical limb ischemia $(n=6)$ in patients with severe comcomitant atherosclerotic changes in femoropopliteal and crural region. The thrombosis involved an iliac limb of a bifurcated stentgraft $(n=9)$, the whole bifurcated stentgtaft $(n=2)$ and the aortouniiliac $(n=3)$ one. The causes include bifurcated stentgraft limb compression due to narrow distal aneurysmal sac diameters $(n=3)$, stentgraft kinking $(n=3)$, damaged iliac -femoral artery access site $(n=3)$, kinked external iliac artery $(n=1)$, iliac artery AS changes progression $(n=2)$ and hyperkoagulative state $(n=2)$.

All the classical vascular surgical procedures performed in our patients for EVAR corrections were very practicable and technically sucessful. Regional anesthesia was preferred when the inguinal or retroperitoneal ap- proach was used, while general anesthesia was applied in case of transperitoneal approach. We did not use the laparoscopic approach for clip ligation or banding. It is a less invasive procedure, but not one involving less stress, especially in high-risk patients.

In stentgraft thrombosis, we did not use thrombolysis. Surgical thrombectomy is more feasible in this aortoiliac region.

No ilicofemoral bypass was necessary to solve the cause of thrombosis. Stenosed iliac limb $(n=2)$ and iliac artery $(n=3)$ were solved using surgical thrombectomy followed by balloon dilatation supported by wall-stent insertion $(n=2)$. Femoral-femoral bypass is recommended as the last but often is the most simple and useful revascularisation option in one limb of bifurcated stentgraft thrombosis, especially when it is caused by problems with the stentgraft itself.

It is a hemodynamically less stressful and well-accepted type of revascularisation (Fig. 4). Surgical corrections are generally more invasive, especially when extensive approach (retroperitoneal or transperitoneal) is required, but they still involve less hemodynamic stress Multi-centre studies report significantly higher morbidity and mortality rates when the procedures of surgical correction were performed $^{12,30}$. Our single-centre experience produces more favourable results. All the used surgical procedures were well tolerated by the patients and there was no severe morbidity related to the greater invasivenes. According to our current follow-up protocol, angiography (DSA) is performed on the tenth postoperative day, computed tomography angiography (CTA) and plane abdominal 
X-ray are performed annually after it. Based on our 10year experience, we considered this follow-up screening sufficient ${ }^{25,31}$. Regular and thorough follow-up after EVAR is important to identify possible complications at an early stage. At this initial stage, the repair would mostly be technically easy and of a preventive nature to avoid later life or limb threatening complications. In order to determine the exact cause of complications, conventional angiography (DSA) is mostly indicated. Different re-intervention rates are reported for different stentgraft configurations and types. Given the current improvements in the availability of different stentgraft types, it is possible to select one of a quality corresponding with the aorto-iliac anatomy to prevent complications and re-interventions ${ }^{11}$. The bifurcated stentgraft configuration and the Ella (ELLA CS, Hradec Králové, Czech Republic) stentgraft system, which we used in all AAA exclusions, contributed well to the acceptable re-intervention rate in our series ${ }^{23-25}$. The fact that more re-interventions after EVAR were required in high-risk patients (ASA IV) with AAA of complex morphology is a result of extreme EVAR indication in these patients who were unsuitable for open AAA surgery. In such cases, EVAR re-interventions involve a significantly high risk, especially at later complications stages. There were three such problematic patients who required surgical correction in our group.

Therefore, when extreme AAA morphological indication is necessary (in elderly high risk patients with large AAA), using a combination of EVAR and primary planned procedures of surgical correction (combined strategy) is recommended to facilitate the principle pro-

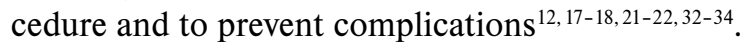

\section{CONCLUSION}

According to our experience with surgical corrections and the results, we can confirm it to be useful for the repair of some EVAR complications and recommended as an adequate option; easy and quick to perform, and reliable and safe, despite its invasiveness.

\section{REFERENCES}

1. Laheij RJF, Buth J, Harris PL, Moll FL, Stelter WJ, Verhoeven ELG. (2000) Need for secondary interventions after endovascular repair of abdominal aortic aneurysms. Intermediate-term follow-up results of a European collaborative registry EUROSTAR). Br J Surg 87, 1666-1673.

2. Ohki T, Veith FJ, Shaw P, Lipsitz E, Suggs WD, Wain RA. (2001) Increasing incidence of midterm and long-term complications after endovascular graft repair of abdominal aortic aneurysms: a note of caution based on a 9-year experience. Ann Surg 234, 323-334.

3. Cao P, Verzini F, Parlani G, Romano L, De Rango P, Pagliuca V. (2004) Clinical effect of abdominal aortic aneurysm endografting: 7 -year concurent comparison with open repair. J Vasc Surg 40, 841-848.

4. EVAR Trial participants. Endovascular aneurysm repair versus open repair in patients with abdominal aortic aneurysm (EVAR trial 1): randomised controlled trial. (2005) Lancet 365, 21792186.
5. Blankenstein JD, de Jong SE, Prinssen M, van der Ham AC, Buth J, van Sterkenburg SM. (2005) Two-years outcomes after conventional or endovascular repair of abdominal aortic aneurysms.N Engl J Med 352, 2398-2405.

6. May J, White GH, Waugh R, Petrasek P, Chaufour X, Arulchelvam M, Stephen MS, Harris JP. ( 2000) Life-table analysis of primary and assisted success following endoluminal repair of abdominal aortic aneurysm: the role of supplementary endovascular intervention in improving outcome. Eur J Vasc Endovasc Surg 19, 648-655.

7. Datillo J, Brewster DC, Fan CM, Celler SC, Cambria RP, Lamuraglia GM. (2002) Clinical failures of endovascular abdominal aortic aneurysm repair: incidence, causes, and management. $\mathbf{J}$ Vasc Surg 35(6), 1137-1147.

8. Sampram ES, Karafa MT, Mascha EJ, Clair DG, Greenberg RK, Lyden SP, O'Hara PJ, Sarac TP, Srivastava SD, Butler B, Ouriel K. (2003) Nature, frequency and predictors of secondary procedures after endovascular repair of abdominal aortic aneurysm. J Vasc Surg 37, 930-937.

9. Flora HS, Chaloner EJ, Sweeney A, Brookes J, Raphael MJ, Adiseshiah M. (2003) Secondary intervention following endovascular repair of abdominal aortic aneurysm: a single centre experience. Eur J Vasc Endovasc Surg 26, 287-292.

10. Bequemnin JP, Kelley L, Zubilewicz T, Desgranges P, Lapeyere M, Kobeiter H. (2004) Outcomes of secondary interventions after abdominal aortic aneurysm endovascular repair. J Vasc Surg 39, 298-305.

11. Verhoeven ELG, Tielliu IFJ, Prins TR, Zeebregts CJAM, van Andringa de Kempenaer MG, Cina CS, van den Dungen JJAM. (2004) Frequency and outcome of re-interventions after endovascular repair for abdominal aortic aneurysm: a prospective cohort study. Eur J Vasc Endovasc Surg 28, 357-364.

12. Hobo R, vanMarrewijk CJ, Leurs LJ, Laheij RJF, Buth J on behalf of the EUROSTAR collaborators. (2005) Adjuvant procedures performed during endovascular repair of abdominal aortic aneurysm. Does it influence outcome? Eur J vasc Endovasc Surg 30, 20-28.

13. Ivancev K, Chuter T, Lindh M, Lindbladt B, Brunkwall J, Risberg B. (1996) Options for treatment of persistent aneurysm perfusion after endovascular repair. World J Surg 20, 673-678.

14. Dorffner R, Thurnher S, Polterauer P, Kretschmer G, Lammer J. (1997) Treatment of abdominal aortic aneurysms with transfemoral placement of stentgrafts: complications and secondary radiologic intervention. Radiology 204, 79-86.

15. Tibballs JM, van Schie G P, Sieunarine K, Lawrence-Brown MMD, Hartley D, Goodman MA, Prendergast FJ. (1998) Endovascular conversion procedure for failed primary endovascular aortic stentgrafts. Cardiovasc Intervent Radiol 21, 79-83.

16. May J, White GH, Yu W. (1995) Surgical management of complications following endoluminal grafting of abdominal aortic aneurysm. Eur J Vasc Endovasc Surg 10, 51-59.

17. Chaikoff EL, Blankenstein JD, Harris PL, White GH, Zarins ChK, Bernhard VM, Matsumura JS, May J, Veith FJ, Fillinger MF, Rutherford RB, Kent KG, for the Ad Hoc Committee for Standardized Reporting Practices in Vascular Surgery of the Society for Vascular Surgery/American Association for Vascular Surgery. (2002) Reporting standards for endovascular aortic aneurysm repair. J Vasc Surg, 35, 1048-1060.

18. Utíkal P, Köcher M, Bachleda P, Dráć P, Buriánková E, Kojecký Z, Ürge J. (2001) Léčba AAA na přelomu tisíciletí - stentgrafting - role cévního chirurga. Prakt Flebol 10, 111-113.

19. Hölzenbein TJ, Kretschmer G, Dorffner R, Thurnher S, Sandner D, Minar E, Lammer J, Polterauer P. (1998) Endovascular management of „Endoleaks“ after transluminal infrarenal abdominal aneurysm repair. Eur J Vasc Endovasc Surg 16, 208-217.

20. Sonesson B, Montgomery A, Ivancev K, Lindblad B. (2001) Fixation of infrarenal aortic stent-grafts using laparoscopic bandigan experimental study in pigs. Eur J Vasc Endovas Surg 21, 4045.

21. Utíkal P, Köcher M, Bachleda P, Dráč P, Černá M, Buriánková E. (2004) Banding in aortic stent-graft fixation in EVAR. Biomed Pap Med Fac Univ Palacky Olomouc 148,175-178. 
22. Utíkal P, Köcher M, Koutná J, Bachleda P, Dráč P, Černá M, Buriánková E, Herman J. (2005) Combined strategy in AAA elective treatment. Biomed Pap Med Fac Univ Palacky Olomouc 149, 159-163.

23. Utíkal P, Köcher M, Bachleda P, Novotný J, Ürge J, Dráč P. (2000) Tř́leté zkušenosti stentgraftingem AAA ve FN UP v Olomouci. Prakt Flebol 9,175-179.

24. Köcher M, Utíkal P, Buriánková E, Koutná J, Bachleda P, | Novotný J, Heřman M, Benýšek V, Bučil J, Černá M. (2001) Čtyřleté zkušenosti se stentgraftem ELLA v endovaskulární léčbě AAA. Čes Radiol 55, 159-166.

25. Köcher M, Utíkal P, Koutná J, Bachleda P, Buriánková E, Heřman M, Bučil J, Benýšek V, Černá M, Kojecký Z. (2004) Endovascular treatment of abdominal aortic aneurysms-6 years of experience with Ella stent-graft system. Eur J of Radiol 51, 181-188.

26. Köcher M, Utíkal P, Bachleda P, Novotný J. (2001) Endovascular conversion - the possible solution of intersegmental endoleak in patient with AAA treated by bifurcated type of stentgraft. Eur J Vasc Endovasc Surg, Extra - online version.

27. White G H, May J, Petrasek P. (2000) Specific complications of endovascular aortic repair. Semin Intervent Cardiol 5, 35-46

28. vanMarrewijk C, Buth J, Harris PL, Norgren L, Nevelsteen A, Wyat MG. (2002) Significance of endoleaks after endovascular repair of abdominal aortic aneurysms: The EUROSTAR experience. J Vasc Surg 34, 461-473.

29. Boyle JR, Thompson MM, Clode-Baker EG. (1998) Torsion and kinking of unsupported aortic stentgrafts: Treatment by endovascular intervention. J Endovasc Surg 5, 216-221

30. Lee WA, Berceli SA, Huber TS, Ozaki CK, Flyn TC, Seeger JM. (2003) Morbidity with retroperitoneal procedures during ednovasculat abdominal aortic aneurysm repair. J Vasc Surg 38, 459-463.

31. Černá M, Köcher M, Utíkal P, Benýšek V, Bučil J, Heřman M, Bachleda P, Koutná J. (2005) Úprava protokolu sledování nemocných po endovaskulární léčbě aneuryzmatu abdominální aorty na základě retrospektivní analýzy vývoje velikosti vaku aneuryzmatu a výskytu endoleaků. Čes Radiol 59,153-161.

32. May J, White GH, Yu W, Waugh RC, Stephen MS. Harris JP. (1996) Results of endoluminal grafting of abdominal aortic aneurysms are dependent on aneurysm morphology. Ann Vasc Surg 10, 254-261.

33. Yano OJ, Faries PL, Morrisey N, Teodorescu V, Hollier LH, Marin ML. (2001) Ancillary techniques to facilitate endovascular repair of aortic aneurysms. J Vasc Surg 34, 69-75.

34. Greenberg RK, Clair D, Srivastava S, Bhandari G, Turc A, Hampton J. (2003) Should patients with challenging anatomy be offered endovascular aneurysm repair? J Vasc Surg 38, 990-996. 